\title{
The Continuing Evolution of Insulin-like Growth Factor
}

\section{Signaling [version 1; peer review: 4 approved]}

\author{
Steven A Rosenzweig (10)
}

Department of Cell and Molecular Pharmacology \& Experimental Therapeutics, Medical University of South Carolina, Charleston, SC, 29425, USA

V1 First published: 23 Mar 2020, 9(F1000 Faculty Rev):205

https://doi.org/10.12688/f1000research.22198.1

Latest published: 23 Mar 2020, 9(F1000 Faculty Rev):205

https://doi.org/10.12688/f1000research.22198.1

\section{Abstract}

The insulin-like growth factors (IGFs; IGF1/IGF2), known for their regulation of cell and organismal growth and development, are evolutionarily conserved ligands with equivalent peptides present in flies (D. melanogaster), worms (C. elegans) among others. Two receptor tyrosine kinases, the IGF1 receptor and the insulin receptor mediate the actions of these ligands with a family of IGF binding proteins serving as selective inhibitors of IGF1/2. This treatise reviews recent findings on IGF signaling in cancer biology and central nervous system function. This includes overexpression of IGF1 receptors in enhancing tumorigenesis, acquired resistance and contributions to metastasis in multiple cancer types. There is accumulating evidence that insulin resistance, a hallmark of type 2 diabetes, occurs in the central nervous system, independent of systemic insulin resistance and characterized by reduced insulin and IGF1 receptor signaling, and may contribute to dementias including Alzheimer's Disease and cognitive impairment. Controversy over the role(s) of IGF signaling in cancer and whether its inhibition would be of benefit, still persist and extend to IGF1's role in longevity and central nervous system function.

\section{Keywords}

insulin-like growth factor1, signaling, cancer, Alzheimer's disease, dementia, type 2 diabetes, insulin resistance

\section{Open Peer Review}

\begin{tabular}{|c|c|c|c|c|}
\hline \multicolumn{5}{|c|}{ Approval Status $\checkmark$} \\
\hline & 1 & 2 & 3 & 4 \\
\hline $\begin{array}{l}\text { version } 1 \\
23 \operatorname{Mar} 2020\end{array}$ & . & $\checkmark$ & $\checkmark$ & $\checkmark$ \\
\hline
\end{tabular}

Faculty Reviews are review articles written by the prestigious Members of Faculty Opinions. The articles are commissioned and peer reviewed before publication to ensure that the final, published version is comprehensive and accessible. The reviewers who approved the final version are listed with their names and affiliations.

1. Derek LeRoith, Icahn School of Medicine at Mount Sinai, New York, USA

2. Douglas Yee, University of Minnesota, Minneapolis, USA

3. Cunming Duan, University of Michigan, Ann Arbor, USA

4. W Todd Miller, Stony Brook University, Stony Brook, USA

Any comments on the article can be found at the end of the article. 
Corresponding author: Steven A Rosenzweig (rosenzsa@musc.edu)

Author roles: Rosenzweig SA: Conceptualization, Writing - Original Draft Preparation, Writing - Review \& Editing

Competing interests: No competing interests were disclosed.

Grant information: The author(s) declared that no grants were involved in supporting this work.

Copyright: $\odot 2020$ Rosenzweig SA. This is an open access article distributed under the terms of the Creative Commons Attribution

License, which permits unrestricted use, distribution, and reproduction in any medium, provided the original work is properly cited.

How to cite this article: Rosenzweig SA. The Continuing Evolution of Insulin-like Growth Factor Signaling [version 1; peer review: 4 approved] F1000Research 2020, 9(F1000 Faculty Rev):205 https://doi.org/10.12688/f1000research.22198.1

First published: 23 Mar 2020, 9(F1000 Faculty Rev):205 https://doi.org/10.12688/f1000research.22198.1 


\section{Introduction}

IGF-1 and members of the IGF family

In mammals, the insulin-like growth factor (IGF) family comprises three ligands-IGF-1, IGF-2, and insulin-and three receptors-the IGF-1 receptor (IGF1R), insulin receptor (IR), and IGF-2 receptor (IGF2R). The IGF1R and IR are structurally related heterotetrameric receptor tyrosine kinases (RTKs), with the IR having two alternatively spliced isoforms, IRA and IRB, whose functions are incompletely understood ${ }^{1,2}$. The IR isoforms were recently shown to be regulated by their IGFbinding affinities and principally that of IGF-2 rather than their insulin-binding affinities; IGF-2 binds to IRA and IGF1R and is a more potent mitogen than IGF- ${ }^{3}$. IRB modulates metabolic actions in adults while IRA functions in prenatal growth and development and mediates the mitogenic effects of insulin ${ }^{4}$. IRA homodimers and IRA/IGF1R heterodimers have mitogenic actions and stimulate cancer cell growth ${ }^{5}$. While beyond the scope of this review, it is noteworthy that considerable progress has been made in defining the 3D structure of the IGF1R and delineating how IGF-1 binds to and activates the receptor ${ }^{6-9}$. The IGF2R, also known as the mannose-6-phospate (M6P) receptor, is acknowledged for targeting newly synthesized lysosomal hydrolases from the endoplasmic reticulum to lysosomes. The IGF2R lacks a signaling function and instead binds to IGF-2 at the cell surface and clears it via receptor-mediated endocytosis and lysosomal degradation. IGF2 is an imprinted gene expressed only from the paternal allele ${ }^{10,11}$.

In addition to the ligands and receptors, there is a family of six IGF-binding proteins (IGFBPs) exhibiting higher affinities $(\mathrm{pM})$ for the IGFs than their cognate receptors (nM) that serve to tightly regulate IGF-1 and IGF-2 levels/bioavailability in the circulation and at the cell surface ${ }^{12}$. Importantly, the IGFBPs lack any measurable affinities or selectivity for insulin, raising the following question: why are there six $\operatorname{IGFBPs}^{13}$ and no insulin BPs? Consistent with these proteins' evolutionary conservation, in addition to ligands and receptors, a recent report described the presence of an ancestral IGF-1/insulin-binding $\operatorname{protein}^{14,15}$. While there is no agreed-upon or absolute answer to this conundrum, a key piece of this puzzle relates to the sites and manner of insulin biosynthesis compared to that of the IGFs. Insulin biosynthesis occurs in the beta cells of the pancreatic islets of Langerhans, where it is stored in granules until it is needed in response to elevated glucose levels. In contrast, IGF-1 and IGF-2 are made by a number of cells where they undergo constitutive secretion rather than being stored in their cells of origin and serve as paracrine/autocrine factors. IGF-1 and IGF-2 are also synthesized and released into the circulation by the liver, where they exist free, in binary complexes with the IGFBPs or in ternary complexes of $\sim 140 \mathrm{kDa}$ with IGFBP3 or IGFBP5 plus an acid labile subunit prolonging its circulating half-life from hours to days following its secretion ${ }^{16}$. IGF-1 production is under the control of pituitary growth hormone after birth $^{11}$.

It is noteworthy that in humans there is a single insulin, IGF-1, and IGF-2, whereas Drosophila has eight Drosophila insulin-like peptides (DILP-1-8) and Caenorhabditis elegans has upwards of 40 ILPs (reviewed in 14). In Drosophila, insulinlike polypeptide-binding protein (IBP) serves as an IGFBP homolog that was shown to have $\mathrm{nM}$ binding affinity with the following order of affinity: DILP-5 ( $\left.\mathrm{K}_{\mathrm{d}} 2 \mathrm{nM}\right)>$ IGF-1 $\left(\mathrm{K}_{\mathrm{d}} 13.6 \mathrm{nM}\right)>$ insulin $\left(\mathrm{K}_{\mathrm{d}} 135 \mathrm{nM}\right)^{14}$. Crystallographic studies on Drosophila imaginal morphogenesis protein-late 2 protein (Imp-L2) bound to DILP-5 and bound to IGF-1 revealed that the overall structure of 1mp-L2 differs significantly from that of the IGFBPs, comprising two immunoglobulin-like fold domains ${ }^{14}$. To obtain more-detailed information on the contact sites between Imp-L2 and IGF-1, Pompach and co-workers used IGF-1 or des(63-70)-IGF-1, which lacks the C-terminal octapeptide and the loss of two out of three lysyl residues that were derivatized on their amino groups ( $\mathrm{N}$-terminal and lysyl residues), with a heterobifunctional cross-linker in order to photocrosslink complexes of Imp-L2:IGF-1 in a manner that went beyond previous photoaffinity labeling studies of IGFBP $2^{17}$, enabling the co-identification of where different IGF-1 domains contact Imp-L2 ${ }^{15}$. It was suggested that the regulation of ILP bioavailability is likely represented by an alternative strategy to the IGFBPs given their structural differences to the IGFBPs; because of the highly conserved nature of the IBPs in insects, this system may be exploited as a future therapeutic target for blocking the transmission of insect-borne diseases such as malaria ${ }^{14}$. Of note, the ILPs signal through a single insulin receptor-like receptor ${ }^{18}$, with DILP-8 signaling through a G-protein-coupled receptor, $\operatorname{Lgr} 3^{19}$. This differs from humans, in whom signaling is mediated by the IGF1R, IGF2R, IRA, IRB, and associated hybrid heterotetramers. This suggests that ligand diversity in insects preceded receptor diversity, with greater ligand regulation occurring through the IBPs. The role of IGF-1 signaling in cancer and Alzheimer's disease $(A D)$ will be the focus of the remainder of this treatise.

\section{IGF-1 and cancer}

IGF-1 signaling plays a role in cancer tumorigenesis and metastasis, which led to the IGF1R becoming a therapeutic target for multiple cancer sites ${ }^{20,21}$. Accordingly, a number of smallmolecule RTK inhibitors (RTKIs) and monoclonal antibodies (mAbs) targeting the IGF-binding domain on the IGF1R were developed for use in treating cancer. To date, all of these strategies have failed in clinical trials, primarily owing to the onset of acquired resistance ${ }^{22,23}$. In reviewing anti-IGF therapeutics in breast cancer, Yee suggested that failure of the first generation of IGF1R inhibitors has unfairly reduced confidence in their use and that, as we learn from these mistakes, the death knell for these inhibitors may have been premature ${ }^{24}$. Instead, he advocates that by identifying and then applying predictive biomarkers, a cohort of patients with IGF1R-driven tumors who will be more likely to respond positively to treatment may be identified; this approach has exhibited success in analyzing patients with lung cancer $^{25}$. It is notable that the IGF1R-targeting $\mathrm{mAb}$ teprotumumab was tested for safety and efficacy in a multicenter, double-masked, randomized, placebo-controlled trial in patients with active, moderate-to-severe ophthalmopathy 
associated with Graves' disease ${ }^{26}$. Teprotumumab (Tepezza®) was approved for use in January 2020 and is the first drug for use in adults for treating thyroid eye disease.

Over the years, serum levels of IGF-1, IGF-2, and IGFBP3 have been evaluated as predictive biomarkers for breast and prostate cancers, with elevated IGF-1 levels being assigned as a risk factor for prostate cancer ${ }^{27}$. A review of the population-based epidemiologic studies reaffirmed the association of high serum IGF-1 levels with breast, prostate, colorectal, and other cancers $^{28}$. While these results remain controversial, it was recently reported that either low levels of IGFBP1 or elevated levels of IGF-1 increase the risk for prostate cancer ${ }^{29}$. In that context, transgenic mice overexpressing IGF-1 in prostate epithelial cells exhibited spontaneous formation of prostate adenocarcinomas $^{30}$. To more directly address the question of whether elevated circulating IGF-1 levels contribute to prostate cancer, Wang and colleagues crossed transgenic mice overexpressing hepatic IGF-1 (HIT mice) with mice overexpressing human $\mathrm{c}-\mathrm{Myc}$ in the prostate driven by the androgenresponsive probasin (ARR2Pb) promoter (Hi-Myc). These studies revealed that elevated serum IGF-1 in the Hi-Myc/HIT mice was associated with prostate enlargement, invasive prostate cancer, and more-aggressive prostate adenocarcinoma, which did not occur in Hi-Myc mice with normal levels of serum IGF- $1^{31}$. In $C$. elegans, elevated insulin/IGF-1 led to accumulation of the human forkhead box O3A gene (FOXO3A), a transcription factor/daf-16 homolog in $C$. elegans and downstream target of insulin/IGF-1 signaling that regulates lifespan and metabolism in lower organisms ${ }^{32}$. FOXO3A expression is also associated with longevity in humans based on greater expression of FOXO3A polymorphisms (single nucleotide polymorphisms) in centenarians and nonagenarians compared to younger controls, suggesting that FOXO3A may be a susceptibility gene for prolonged survival in humans ${ }^{33}$. FOXO3A is downstream of IGF1R signaling and activation of phosphoinositide 3-kinase (PI3K), phosphoinositide-dependent kinase 1 (PDK1), and Ak strain transforming (Akt; also known as protein kinase $\mathrm{B})^{34}$ and regulates the activation/inhibition of multiple target genes. In this pro-survival signaling pathway, activated Akt enters the nucleus and phosphorylates FOXO3A, downregulating Bcl-2-interacting mediator of cell death (Bim) to inhibit apoptosis and promote cell proliferation.

Pan and co-workers demonstrated that primary (not acquired) resistance to the epidermal growth factor receptor (EGFR) TKI gefitinib $^{22}$ in non-small cell lung cancer (NSCLC) cell lines was due, in part, to IGF1R signaling ${ }^{35}$. They further showed that combining gefitinib with the oral hypoglycemic drug metformin restored gefitinib sensitivity to resistant NSCLC (H1975) cells, resulting in decreased phospho-Akt (pAkt) levels and elevated Bim expression ${ }^{35}$. In this regard, Qiu and co-workers ${ }^{36}$ reported that both primary and acquired resistance of breast cancer cell lines to the anti-human epidermal growth factor receptor 2 (HER2) mAb trastuzumab are both increased by Cullin7 (CUL7), a scaffold protein for the CUL7 E3 ubiquitin ligase that is overexpressed in the trastuzumab-resistant cells. The principal target of the CUL7 E3 ligase is Ser-phosphorylated insulin receptor substrate 1 (IRS1), a form of IRS1 that lacks the ability to signal through the PI3K/Akt pathway because of its reduced ability to be tyrosine (Tyr)-phosphorylated ${ }^{37}$. Accordingly, CUL7 overexpression favors signaling through Tyr-phosphorylated IRS1, which is reinforced by CUL7 degradation of IGFBP3, in turn raising IGF-1 levels and IGF1R signaling, which then enhances resistance to trastuzumab ${ }^{36}$. Related to these findings, Yang and co-workers reported that the tyrphostin NT157 downregulates IRS1/2 proteins in breast cancer cell lines by binding to the IGF1R, increasing serine phosphorylation of IRS1/2, leading to their degradation and reduced IGF1R signaling ${ }^{38}$. Both of these studies provide support for targeting IRS protein degradation in NSCLC and breast cancer. While the mechanism of IRS degradation has yet to be defined ${ }^{38}$, Qiu et al. ${ }^{36}$ suggest that CUL7 levels may serve as a biomarker for trastuzumab responsiveness and combination therapy employing CUL7 deletion and trastuzumab.

\section{The brain IGF system: neurodegenerative disease and cognition}

In addition to its well-known hormonal function regulating growth and influencing fuel metabolism and lifespan, the IGF system (including insulin signaling) has received considerable attention in recent years for its role in the central nervous system (CNS). Unlike insulin, which is exclusively synthesized by the beta cells of the pancreatic islets of Langerhans, IGF-1 is synthesized within various brain regions by neurons, glial cells, and endothelial cells, with systemic IGF-1 also accessing the brain by crossing the blood-brain barrier $(\mathrm{BBB})^{39}$. The role played by insulin and the IGFs in the CNS has been linked to brain development, metabolism, injury repair, cognition, and $\operatorname{mood}^{40}$. Consequently, loss of insulin/IGF-1 signaling in the brain, mediated by both the IR and the IGF1R, has generally been associated with an elevated risk of $\mathrm{AD}$, cognitive decline, (premature) dementia, depression, and anxiety ${ }^{41-43}$. IGF-1 signaling plays multiple roles in the CNS, and its potential beneficial role in $\mathrm{AD}$ and other dementias helps make the case for the IGF system as a therapeutic target in neurodegenerative diseases, including $\mathrm{AD}^{16}$. In this context, IGF-1 functions both as a hormone following access of systemically produced IGF-1 to the CNS and as a locally produced autocrine/paracrine factor whose levels are tightly regulated by CNS-produced IGFBPs ${ }^{12}$.

Mice with reduced levels of circulating IGF-1 (resulting from targeted disruption of hepatic IGF-1 expression) exhibit cognitive deficiencies based on impaired performance in a hippocampal-dependent spatial-recognition task and disrupted long-term potentiation (LTP $)^{44}$. These deficits are reversed by systemic administration of IGF-1, which normalized glutamatergic boutons in the hippocampus that were reduced in mice with low serum IGF-1 ${ }^{44}$. In testing the impact of loss of insulin/IGF-1 signaling in the brain, Soto and co-workers ${ }^{45}$ generated double knockout (DKO) mice with inactivated IR/IGF1R in the hippocampus (Hippo-DKO) or the central amygdala (CeA-DKO). These studies confirmed that spatial learning and memory require insulin/IGF-1 signaling in the hippocampus while insulin/IGF-1 signaling in the central amygdala mediates thermogenesis ${ }^{45}$. Based on 7 Tesla MRI brain imaging of human subjects, elevating peripheral IGF-1 was positively linked to increased hippocampal volume and memory (verbal recall) ${ }^{46}$. 
An opposing role for IGF-1 in the CNS was the subject of a recent review underscoring that in $\mathrm{AD}$, reducing IGF-1 signaling may serve to clear protein plaques and slow disease progression while at the same time reduced IGF-1 levels may lead to dysregulated cognition and neurovascular function ${ }^{47}$. Based on IGF-1's ability to slow or reverse cognitive decline, quantifying its levels in the circulation has been promoted as a biomarker for cognitive decline ${ }^{48}$. Further support for IGF-1 as a neurotrophic factor comes from work on Parkinson's disease where low serum IGF-1 levels correlated with poor performance on executive tasks in early, drug-naïve patients and may be predictive of poor performance on attention/executive and verbal memory tasks after a 2-year follow-up ${ }^{49}$. Thus, the role of systemic IGF-1 on neurogenesis, cognition, and dementia deserves further analysis.

\section{Type 2 diabetes mellitus, insulin/IGF-1 signaling, and AD}

Controversy concerning the positive versus negative role(s) of insulin/IGF-1 signaling in the brain exists. For example, Kleinridders and co-workers reported that insulin signaling via brain IR/IGF1R alters systemic metabolism and a variety of brain functions ranging from appetite control and body temperature to neuronal function and synaptogenesis, providing evidence for a favorable role ${ }^{50}$. Contradictory findings with respect to the role of insulin/IGF-1 signaling in neurodegenerative disease exist. Specifically, in humans, insulin resistance and type 2 diabetes mellitus (T2DM) are associated with AD. Moreover, patients with diabetes were at higher risk for dementia and patients with diabetes and dementia are at greater risk for severe hypoglycemia ${ }^{51}$. In lower organisms, including Drosophila, C. elegans, and mice, reduced levels of insulin/IGF-1 signaling slows neurodegeneration and increases longevity (reviewed in 52). A similar inverse relationship between longevity and IGF1R levels was reported for 16 distinct rodent species $^{53}$; it did not extend to peripheral tissues or to body mass (which has been shown to be directly related to IGF-1 levels in purebred $\left.\operatorname{dogs}^{54}\right)$. This led the authors to suggest that IGF1R signaling in nervous tissue played a role in the evolution of longevity in mammals ${ }^{53}$. The expression levels of both the IR and the IGF1R are higher in younger mice and decrease as the animals age ${ }^{55}$. As detailed above, insulin/IGF-1 signaling in the CNS is frequently quantified by IRS1/IRS2 phosphorylation, with elevated IRS1/2 serine phosphorylation contributing to AD. The assertion that decreased insulin/IGF-1 signaling contributes to reduced cognitive function supports the therapeutic approach of insulin or IGF-1 treatment in order to enhance cognition. However, contrary observations have been reported in animal models of $\mathrm{AD}$ where reduced insulin/IGF-1 signaling through IR/IGF1R and IRS2 slowed the progression of neurodegeneration, suggesting IRS2 action is a negative regulator of cognition/ dementia $^{56}$. Decreased insulin/IGF-1 signaling is known to increase longevity in C. elegans ${ }^{57}$, Drosophila ${ }^{58}$, and transgenic mice $^{59}$ while lowering the incidence of multiple cancers by reducing tumor growth and metastasis ${ }^{60}$. It is clear that the role of insulin/IGF-1 signaling in aging (beyond examining lifespan in worms, flies, and mice) should also be considered in light of the impact of this signaling pathway on dementia (cognition) and neurogenesis.
Beyond regulating glucose metabolism, insulin and IGF-1 control neuronal and glial cell survival, synapse function, memory, cognition, and anti-inflammatory actions ${ }^{61}$, with evidence for insulin resistance contributing to both the development and the progression of $\mathrm{AD}^{62}$. $\mathrm{AD}$ is characterized by amyloid beta $(A \beta)$ plaques, phospho-tau protein ( $p$-tau) neurofibrillary tangles, cortical neuron loss, and cognitive impairment ${ }^{63,64}$. $\mathrm{A} \beta$ plaques and pTau are the defining characteristics of $\mathrm{AD}$, with glycogen synthase kinase $3 \beta$ (GSK3 $\beta$ ) representing Tau Kinase 1 and the source of an alternative hypothesis of AD in which GSK3 $\beta$ overactivity leads to $\mathrm{AD}^{65,66}$. It has been hypothesized that CNS insulin resistance may play a causal role in both the development and the progression of $\mathrm{AD}$, consistent with insulin's role in brain metabolism and neuronal survival ${ }^{61}$. Of note, insulin and IGF-1 resistance and deficiency are typically observed early in the progression of $\mathrm{AD}$ and the abnormal molecular and biochemical alterations parallel those seen in type 1 diabetes mellitus (T1DM)/T2DM, leading some to use the term "type 3 diabetes mellitus" (T3DM) to reflect the concept that insulin resistance within the brain may cause $\mathrm{AD}^{50,61,67-69}$. A caveat of these studies is that much of what is known about IGF-1/insulin signaling in the CNS is based on studies with rodents; this has been a source of concern with respect to the translation of these findings to humans ${ }^{16}$. A recent review by Arnold and co-workers details the overlap between patients with $\mathrm{AD}$ and $\mathrm{T} 2 \mathrm{DM}$, brain dysfunction in $\mathrm{T} 2 \mathrm{DM}$, and the fact that brain insulin resistance occurring in T2DM may lead to cognitive impairment $^{70}$.

In a recent study examining the relationship between $\mathrm{AD}$ and IGFBP2 levels across a spectrum of 300 human AD patients and two transgenic mouse models of $\mathrm{AD}$, investigators found cerebrospinal fluid (CSF) IGFBP2 levels correlated with CSF tau levels and brain atrophy in non-hippocampal regions ${ }^{71}$. This study linked IGFBP2 levels to tau pathology, which may, in turn, reflect a decrease in IGF-1 signaling resulting from IGF-1 sequestration by IGFBP2. This is consistent with an early observation of localized diabetes within the brain, which noted that, in the absence of systemic symptoms of diabetes, insulin and IGF-1 resistance were detectable in the hippocampus and, to a lesser extent, the cerebellar cortex ${ }^{41-43}$. These measurements were based upon observations of reduced responsiveness to insulin in the IR/IRS1/PI3K cascade and to IGF-1 in the IGF1R/IRS2/PI3K pathway. Reduced signaling through both IRS1 and IRS2 in this context has consistently revealed elevated serine phosphorylation of IRS1 $\left(\mathrm{pS}^{616}, \mathrm{pS}^{636 / 639} / \mathrm{IRS} 2\right)$, mediated by cJun N-terminal kinase (JNK) $1 / 2$, extracellular signal regulated kinase (ERK)1/2, mammalian target of rapamycin (mTOR), AKT, and GSK3 $3 \beta^{41-43,68}$.

\section{T2DM is a risk factor for AD}

$\mathrm{AD}$ is a degenerative metabolic disease caused by brain insulin resistance and deficiency and overlapping with the molecular, biochemical, pathophysiological, and metabolic dysfunction in diabetes mellitus ${ }^{61}$. In this context, insulin, IGF-1, incretins, and insulin sensitizers may be useful for treating different stages of neurodegeneration. Both diseases have a protein-misfolding component, and patients with T2DM have an increased risk for $\mathrm{AD}^{72}$. Streptozotocin (STZ) is a 
glucosamine-nitrosourea diabetogenic agent used to generate T1DM in rodents based on its preferential uptake into pancreatic beta cells via Glut2 transporters, nuclear entry, alkylation of DNA, and beta cell death ${ }^{73}$. At low doses, STZ can induce T2DM and insulin resistance in the CNS following intracerebroventricular administration ${ }^{74,75}$. Insulin and IGF-1 resistance in human T2DM significantly increases the risk of $\mathrm{AD}^{71,76}$. Over the last several years, the increased incidence of $\mathrm{AD}$ and $\mathrm{T} 2 \mathrm{DM}$ in the aging population has emerged. Of note, ineffective insulin/IGF-1 signaling resulting from insulin resistance is a risk factor for $\mathrm{AD}$, where the presence of T2DM doubles the risk of $\mathrm{AD}^{16,61,76}$. Liraglutide, an insulin secretagogue, and other drugs available for treating $\mathrm{T} 2 \mathrm{DM}$ are strong candidates to repurpose for $\mathrm{AD}$ and hit multiple targets, representing an example of polypharmacology over polypharmacy in the repurposing of drugs for their side effects in $\mathrm{AD}^{77}$. In addition, clinical trials testing the efficacy of intranasal administration of long-acting detemir insulin showed that this form of insulin gets into the brain with reduced associated systemic hypoglycemic episodes and mild cognitive improvement ${ }^{78}$. Delivery of intranasal insulin in humans was found to increase dorsal medial PFC-hippocampal functional connectivity with the potential to improve cognition and metabolism ${ }^{79}$. Of note, intranasal administration of insulin in wild-type (WT) mice versus a mouse model of $\mathrm{AD}\left(\mathrm{APP}_{\mathrm{Swe}} / \mathrm{PS} 1_{\mathrm{dE} 9}[\mathrm{APP} / \mathrm{PS} 1]\right.$ transgenic mice) was effective only in the WT mice ${ }^{80}$. The insulin sensitizer metformin is currently being evaluated for use in patients with mild cognitive impairment in a national clinical trial ("Metformin in Alzheimer's Dementia Prevention [MAP]"; NCT04098666).

\section{Conclusion and future perspectives}

As with the ongoing controversy of whether the IGFBPs possess biologic functions independent of the binding and sequestration of the IGFs to directly inhibit or stimulate tumor growth, a similar disagreement in the context of whether centrally acting IGF-1/insulin stimulates or inhibits cognition/ neurogenesis/dementia exists. As additional human studies and clinical trials test the efficacy of insulin/IGF-1 in modulating cognition along with the refinement of their more selective targeting to brain regions like the hippocampus over the hypothalamus, more desirable outcomes may emerge. With respect to the cross-talk between cancer and $\mathrm{AD}$, a recent population-based study showed that patients with a history of cancer had a lower incidence of $\mathrm{AD}^{81}$. It was further noted that older individuals with cancer had better memory and slower memory decline, supporting the hypothesis that there may be a common pathologic process working in an opposing manner in cancer and AD. This study lends further support to this previously identified inverse relationship that has been described by others ${ }^{82,83}$. Though we currently lack a mechanism underlying this phenomenon, it is tempting to speculate that IGF-1 and insulin/IGF-1 signaling could be the common denominator.

\section{Abbreviations}

$\mathrm{A} \beta$, amyloid $\beta$ peptide; $\mathrm{AD}$, Alzheimer's disease; Akt, Ak strain transforming; protein kinase $\mathrm{B}$; Bim, Bcl-2-interacting mediator of cell death; CSF, cerebrospinal fluid; CNS, central nervous system; CUL7, Cullin 7; DILP, Drosophila insulin-like peptide; DKO, double knockout; FOXO3A, forkhead box O3A; GSK3 $\beta$, glycogen synthase kinase $3 \beta$; HIT, hepatic IGF-1 transgenic; IBP, insulin-like polypeptide-binding protein; IGF, insulin-like growth factor; IGFBP, insulin-like growth factor binding protein; IGF1R, insulin-like growth factor 1 receptor; IGF2R, insulin-like growth factor 2 receptor; Imp-L2, imaginal morphogenesis protein-late 2 protein; IR, insulin receptor; IRS, insulin receptor substrate; RTK, receptor tyrosine kinase; mAb, monoclonal antibody; NSCLC, non-small cell lung cancer; PI3K, phosphoinositide 3-kinase; T1DM, type 1 diabetes mellitus; T2DM, type 2 diabetes mellitus; Tyr, tyrosine; STZ, streptozotocin; WT, wild type.
1. Escribano O, Beneit N, Rubio-Longás C, et al.: The Role of Insulin Receptor Isoforms in Diabetes and Its Metabolic and Vascular Complications. J Diabetes Res. 2017; 2017: 1403206

PubMed Abstract | Publisher Full Text | Free Full Text

2. Konur A, Kreutz M, Knüchel R, et al:: Three-dimensional co-culture of human monocytes and macrophages with tumor cells: analysis of macrophage differentiation and activation. Int J Cancer. 1996; 66(5): 645-52. PubMed Abstract | Publisher Full Text

3. Belfiore A, Frasca F, Pandini G, et al:: Insulin receptor isoforms and insulin receptor/insulin-like growth factor receptor hybrids in physiology and disease. Endocr Rev. 2009; 30(6): 586-623.

PubMed Abstract | Publisher Full Text

4. Belfiore A, Malaguarnera R, Vella V, et al.: Insulin Receptor Isoforms in Physiology and Disease: An Updated View. Endocr Rev. 2017; 38(5): 379-431. PubMed Abstract | Publisher Full Text | Free Full Text

5. Denley A, Cosgrove LJ, Booker GW, et al:: Molecular interactions of the IGF system. Cytokine Growth Factor Rev. 2005; 16(4-5): 421-39. PubMed Abstract | Publisher Full Text

6. $\quad F$ Kavran JM, McCabe JM, Byrne PO, et al.: How IGF-1 activates its receptor.
eLife. 2014; 3: pii: e03772.

PubMed Abstract | Publisher Full Text | Free Full Text | F1000 Recommendation

7. Hubbard SR, Miller WT: Closing in on a mechanism for activation. eLife. 2014; 3: e04909.

PubMed Abstract | Publisher Full Text | Free Full Text

8. $\mathrm{F}$ Xu Y, Kong GK, Menting JG, et al.: How ligand binds to the type 1 insulinlike growth factor receptor. Nat Commun. 2018; 9(1): 821. PubMed Abstract | Publisher Full Text | Free Full Text | F1000 Recommendation

9. $\quad \mathrm{F} \mathrm{Li} \mathrm{J}$, Choi E, Yu H, et al:: Structural basis of the activation of type 1 insulinlike growth factor receptor. Nat Commun. 2019; 10(1): 4567. PubMed Abstract | Publisher Full Text | Free Full Text | F1000 Recommendation

10. Eggermann T, Perez de Nanclares G, Maher ER, et al:: Imprinting disorders: a group of congenital disorders with overlapping patterns of molecular changes affecting imprinted loci. Clin Epigenetics. 2015; 7: 123. PubMed Abstract | Publisher Full Text | Free Full Text

11. F Giabicani E, Chantot-Bastaraud S, Bonnard A, et al:: Roles of Type 1 Insulin-Like Growth Factor (IGF) Receptor and IGF-II in Growth Regulation: Evidence From a Patient Carrying Both an 11p Paternal Duplication and 15q Deletion. Front 
Endocrinol (Lausanne). 2019; 10: 263

PubMed Abstract | Publisher Full Text | Free Full Text | F1000 Recommendation

12. Rosenzweig SA: What's new in the IGF-binding proteins? Growth Horm IGF Res. 2004; 14(5): 329-36.

PubMed Abstract | Publisher Full Text | Free Full Text

13. F Allard JB, Duan C: IGF-Binding Proteins: Why Do They Exist and Why Are There So Many? Front Endocrinol (Lausanne). 2018; 9: 117.

PubMed Abstract | Publisher Full Text | Free Full Text | F1000 Recommendation

14. F Roed NK, Viola CM, Kristensen O, et al:: Structures of insect Imp-L2 suggest an alternative strategy for regulating the bioavailability of insulin-like hormones. Nat Commun. 2018; 9(1): 3860

PubMed Abstract | Publisher Full Text | Free Full Text | F1000 Recommendation

15. F Pompach P, Viola CM, Radosavljević J, et al.: Cross-Linking/Mass Spectrometry Uncovers Details of Insulin-Like Growth Factor Interaction With Insect Insulin Binding Protein Imp-L2. Front Endocrinol (Lausanne). 2019; 10: 695.

PubMed Abstract | Publisher Full Text | Free Full Text | F1000 Recommendation

16. F Lewitt MS, Boyd GW: The Role of Insulin-Like Growth Factors and Insulin Like Growth Factor-Binding Proteins in the Nervous System. Biochem Insights. 2019; 12: 1178626419842176

PubMed Abstract | Publisher Full Text | Free Full Text | F1000 Recommendation

17. Horney MJ, Evangelista CA, Rosenzweig SA: Synthesis and characterization of insulin-like growth factor (IGF)-1 photoprobes selective for the IGF-binding proteins (IGFBPS). photoaffinity labeling of the IGF-binding domain on IGFBP-2. J Biol Chem. 2001; 276(4): 2880-9.

PubMed Abstract | Publisher Full Text

18. Nässel DR, Liu Y, Luo J: Insulin/IGF signaling and its regulation in Drosophila. Gen Comp Endocrinol. 2015; 221: 255-66.

PubMed Abstract | Publisher Full Text

19. F Vallejo DM, Juarez-Carreño S, Bolivar J, et al:: A brain circuit that synchronizes growth and maturation revealed through Dilp8 binding to Lgr3. Science. 2015; 350(6262): aac6767.

PubMed Abstract | Publisher Full Text | F1000 Recommendation

20. Rosenzweig SA, Atreya HS: Defining the pathway to insulin-like growth factor system targeting in cancer. Biochem Pharmacol. 2010; 80(8): 1115-24. PubMed Abstract | Publisher Full Text | Free Full Text

21. F Osher E, Macaulay VM: Therapeutic Targeting of the IGF Axis. Cells. 2019; 8(8): pii: E895.

PubMed Abstract | Publisher Full Text | Free Full Text | F1000 Recommendation

22. Rosenzweig SA: Acquired resistance to drugs targeting receptor tyrosine kinases. Biochem Pharmacol. 2012; 83(8): 1041-8. PubMed Abstract | Publisher Full Text | Free Full Text

23. Rosenzweig SA: Acquired Resistance to Drugs Targeting Tyrosine Kinases. Adv Cancer Res. 2018; 138: 71-98.

PubMed Abstract | Publisher Full Text | Free Full Tex

24. F Yee D: Anti-insulin-like growth factor therapy in breast cancer. $J \mathrm{Mo}$ Endocrinol. 2018; 61(1): T61-T68.

PubMed Abstract | Publisher Full Text | F1000 Recommendation

25. F Kim ES, Herbst RS, Wistuba II, et al.: The BATTLE trial: personalizing therapy for lung cancer. Cancer Discov. 2011; 1(1): 44-53.

PubMed Abstract | Publisher Full Text | Free Full Text | F1000 Recommendation

26. F Smith TJ, Kahaly GJ, Ezra DG, et al:: Teprotumumab for Thyroid-Associated Ophthalmopathy. N Engl J Med. 2017; 376(18): 1748-61.

PubMed Abstract | Publisher Full Text | Free Full Text | F1000 Recommendation

27. Chan JM, Stampfer MJ, Giovannucci E, et al.: Plasma insulin-like growth factor-I and prostate cancer risk: a prospective study. Science. 1998; 279(5350): 563-6. PubMed Abstract | Publisher Full Text

28. Pollak MN, Schernhammer ES, Hankinson SE: Insulin-like growth factors and neoplasia. Nat Rev Cancer. 2004; 4(7): 505-18

PubMed Abstract | Publisher Full Text

29. Cao Y, Nimptsch K, Shui IM, et al.: Prediagnostic plasma IGFBP-1, IGF-1 and risk of prostate cancer. Int J Cancer. 2015; 136(10): 2418-26. PubMed Abstract | Publisher Full Text | Free Full Text

30. DiGiovanni J, Kiguchi K, Frijhoff A, et al.: Deregulated expression of insulin-like growth factor 1 in prostate epithelium leads to neoplasia in transgenic mice. growth factor 1 in prostate epithelium leads to
Proc Natl Acad Sci U S A. 2000; 97(7): 3455-60. PubMed Abstract | Publisher Full Text | Free Full Text

31. F Wang S, Wang N, Yu B, et al.: Circulating IGF-1 promotes prostate adenocarcinoma via FOXO3A/BIM signaling in a double-transgenic mouse model. Oncogene. 2019; 38(36): 6338-53.

PubMed Abstract | Publisher Full Text | F1000 Recommendation

32. F Admasu TD, Chaithanya Batchu K, Barardo D, et al.: Drug Synergy Slows Aging and Improves Healthspan through IGF and SREBP Lipid Signaling. Dev Cell. 2018: 47(1): 67-79.e5.

PubMed Abstract | Publisher Full Text | F1000 Recommendation

33. F Flachsbart $F$, Caliebe A, Kleindorp $\mathrm{R}$, et al.: Association of FOXO3A variation with human longevity confirmed in German centenarians. Proc Natl Acad Sci U S A. 2009; 106(8): 2700-5

PubMed Abstract | Publisher Full Text | Free Full Text | F1000 Recommendation
34. F Liu Y, Ao X, Ding W, et al:: Critical role of FOXO3a in carcinogenesis. Mol Cancer. 2018; 17(1): 104

PubMed Abstract | Publisher Full Text | Free Full Text | F1000 Recommendation

35. $\mathrm{F}$ Pan $\mathrm{YH}$, Jiao L, Lin CY, et al:: Combined treatment with metformin and gefitinib overcomes primary resistance to EGFR-TKIs with EGFR mutation via targeting IGF-1R signaling pathway. Biologics. 2018; 12: 75-86.

PublMed Abstract | Publisher Full Text | Free Full Text | F1000 Recommendation

36. F Qiu N, He YF, Zhang SM, et al.: Cullin7 enhances resistance to trastuzumab therapy in Her2 positive breast cancer via degrading IRS-1 and downregulating IGFBP-3 to activate the PI3K/AKT pathway. Cancer Lett. 2019; 464: $25-36$

PubMed Abstract | Publisher Full Text | F1000 Recommendation

37. Sarikas A, Xu X, Field LJ, et al:: The cullin7 E3 ubiquitin ligase: a novel player in growth control. Cell Cycle. 2008; 7(20): 3154-61.

PubMed Abstract | Publisher Full Text | Free Full Text

38. F Yang Y, Chan JY, Temiz NA, et al.: Insulin Receptor Substrate Suppression by the Tyrphostin NT157 Inhibits Responses to Insulin-Like Growth Factor-I and Insulin in Breast Cancer Cells. Horm Cancer. 2018; 9(6): 371-82. PubMed Abstract | Publisher Full Text | Free Full Text | F1000 Recommendation

39. Yan H, Mitschelen M, Bixler GV, et al:: Circulating IGF1 regulates hippocampal IGF1 levels and brain gene expression during adolescence. J Endocrinol. 2011; 211(1): 27-37.

PubMed Abstract | Publisher Full Text | Free Full Text

40. Fernandez AM, Torres-Alemán I: The many faces of insulin-like peptide signalling in the brain. Nat Rev Neurosci. 2012; 13(4): 225-39. PubMed Abstract | Publisher Full Text

41. Kopf D, Frölich L: Risk of incident Alzheimer's disease in diabetic patients: a systematic review of prospective trials. J Alzheimers Dis. 2009; 16(4): 677-85. PubMed Abstract | Publisher Full Text

42. Eaton WW, Armenian H, Gallo J, et al.: Depression and risk for onset of type II diabetes. A prospective population-based study. Diabetes Care. 1996; 19(10): 1097-102.

PubMed Abstract | Publisher Full Text

43. Talbot $\mathrm{K}$, Wang $\mathrm{HY}$ Kazi $\mathrm{H}$, et al: Demonstrated brain insulin resistance in Alzheimer's disease patients is associated with IGF-1 resistance, IRS-1 dysregulation, and cognitive decline. J Clin Invest. 2012; 122(4): 1316-38. PubMed Abstract | Publisher Full Text | Free Full Text

44. Trejo JL, Piriz J, Llorens-Martin MV, et al: Central actions of liver-derived insulin-like growth factor I underlying its pro-cognitive effects. Mol Psychiatry. 2007; 12(12): 1118-28.

PubMed Abstract | Publisher Full Text

45. F Soto M, Cai W, Konishi M, et al:: Insulin signaling in the hippocampus and amygdala regulates metabolism and neurobehavior. Proc Natl Acad Sci U S A. 2019; 116(13): 6379-84.

PubMed Abstract | Publisher Full Text | Free Full Text | F1000 Recommendation

46. Maass A, Düzel S, Brigadski T, et al.: Relationships of peripheral IGF-1, VEGF and BDNF levels to exercise-related changes in memory, hippocampal perfusion and volumes in older adults. Neurolmage. 2016; 131: 142-54. PubMed Abstract | Publisher Full Text

47. F Gubbi S, Quipildor GF, Barzilai N, et al:: $\mathbf{4 0}$ YEARS of IGF1: IGF1: the Jekyll and Hyde of the aging brain. $J$ Mol Endocrinol. 2018; 61(1): T171-T185. PubMed Abstract | Publisher Full Text | Free Full Text | F1000 Recommendation

48. F Frater J, Lie D, Bartlett P, et al:: Insulin-like Growth Factor 1 (IGF-1) as a marker of cognitive decline in normal ageing: A review. Ageing Res Rev. 2018; 42: $14-27$.

PubMed Abstract | Publisher Full Text | F1000 Recommendation

49. Pellecchia MT, Santangelo G, Picillo M, et al.: Insulin-like growth factor1 predicts cognitive functions at 2-year follow-up in early, drug-naïve Parkinson's disease. Eur J Neurol. 2014; 21(5): 802-7.

PubMed Abstract | Publisher Full Text

50. Kleinridders A, Ferris HA, Cai W, et al.: Insulin action in brain regulates systemic metabolism and brain function. Diabetes. 2014; 63(7): 2232-43.

PubMed Abstract | Publisher Full Text | Free Full Text

51. Meneilly GS, Tessier DM: Diabetes, Dementia and Hypoglycemia. Can J Diabetes. 2016; 40(1): 73-6.

PubMed Abstract | Publisher Full Text

52. White MF: IRS2 integrates insulin/IGF1 signalling with metabolism, neurodegeneration and longevity. Diabetes Obes Metab. 2014; 16(Suppl 1): 4-15.

PubMed Abstract | Publisher Full Text

53. Azpurua J, Yang JN, Van Meter M, et al:: IGF1R levels in the brain negatively correlate with longevity in 16 rodent species. Aging (Albany NY). 2013; 5(4): 304-14.

PubMed Abstract | Publisher Full Text | Free Full Text

54. F Sutter NB, Bustamante CD, Chase $\mathrm{K}$, et al:: A single IGF1 allele is a majo determinant of small size in dogs. Science. 2007; 316(5821): 112-5. PubMed Abstract | Publisher Full Text | Free Full Text | F1000 Recommendation

55. Zhao WQ, Chen $\mathrm{H}$, Quon MJ, et al:: Insulin and the insulin receptor in experimental models of learning and memory. Eur J Pharmacol. 2004; 490(1-3): 71-81.

PubMed Abstract | Publisher Full Text 
56. Irvine EE, Drinkwater L, Radwanska K, et al.: Insulin receptor substrate $\mathbf{2}$ is a negative regulator of memory formation. Learn Mem. 2011; 18(6): 375-83. PubMed Abstract | Publisher Full Text | Free Full Text

57. Paradis S, Ruvkun G: Caenorhabditis elegans Akt/PKB transduces insulin receptor-like signals from AGE-1 PI3 kinase to the DAF-16 transcription factor. Genes Dev. 1998; 12(16): 2488-98.

PubMed Abstract | Publisher Full Text | Free Full Text

58. Tatar M, Kopelman A, Epstein D, et al:: A mutant Drosophila insulin receptor homolog that extends life-span and impairs neuroendocrine function. Science. 2001; 292(5514): 107-10.

PubMed Abstract | Publisher Full Tex

59. F Holzenberger M, Dupont J, Ducos B, et al.: IGF-1 receptor regulates lifespan and resistance to oxidative stress in mice. Nature. 2003; 421(6919): 182-7. PubMed Abstract | Publisher Full Text | F1000 Recommendation

60. Kamrava M, Gius D, Casagrande G, et al.: Will targeting insulin growth factor help us or hurt us?: An oncologist's perspective. Ageing Res Rev. 2011; 10(1) 62-70.

PubMed Abstract | Publisher Full Text | Free Full Text

61. F de La Monte SM: Insulin Resistance and Neurodegeneration: Progress Towards the Development of New Therapeutics for Alzheimer's Disease. Drugs. 2017; 77(1): 47-65.

PubMed Abstract | Publisher Full Text | Free Full Text | F1000 Recommendation

62. $F$ Chapman $C D$, Schiöth $\mathrm{HB}$, Grillo $\mathrm{CA}$, et al: Intranasal insulin in Alzheimer's disease: Food for thought. Neuropharmacology. 2018; 136(Pt B): 196-201. PubMed Abstract | Publisher Full Text | F1000 Recommendation

63. Iqbal K, Liu F, Gong CX: Tau and neurodegenerative disease: the story so far. Nat Rev Neurol. 2016; 12(1): 15-27.

PubMed Abstract | Publisher Full Text

64. F Norwitz NG, Mota AS, Norwitz SG, et al.: Multi-Loop Model of Alzheime Disease: An Integrated Perspective on the Wnt/GSK3ß, $\alpha$-Synuclein, and Type 3 Diabetes Hypotheses. Front Aging Neurosci. 2019; 11: 184. PubMed Abstract | Publisher Full Text | Free Full Text | F1000 Recommendation

65. Hooper C, Killick R, Lovestone S: The GSK3 hypothesis of Alzheimer's disease. J Neurochem. 2008; 104(6): 1433-9.

PubMed Abstract | Publisher Full Text | Free Full Text

66. Llorens-Martín M, Jurado J, Hernández F, et al:: GSK-3ß, a pivotal kinase in Alzheimer disease. Front Mol Neurosci. 2014; 7: 46 PubMed Abstract | Publisher Full Text | Free Full Text

67. de La Monte SM, Wands JR: Alzheimer's disease is type $\mathbf{3}$ diabetes-evidence reviewed. J Diabetes Sci Technol. 2008; 2(6): 1101-13. PubMed Abstract | Publisher Full Text | Free Full Text

68. Zemva J, Schubert M: The role of neuronal insulin/insulin-like growth factor-1 signaling for the pathogenesis of Alzheimer's disease: possible therapeutic implications. CNS Neurol Disord Drug Targets. 2014; 13(2): 322-37. PubMed Abstract | Publisher Full Text

69. Steen E, Terry BM, Rivera EJ, et al.: Impaired insulin and insulin-like growth factor expression and signaling mechanisms in Alzheimer's disease--is this type 3 diabetes? J Alzheimers Dis. 2005; 7(1): 63-80. PubMed Abstract | Publisher Full Text

70. F Arnold SE, Arvanitakis Z, Macauley-Rambach SL, et al:: Brain insulin resistance in type 2 diabetes and Alzheimer disease: concepts and conundrums. Nat Rev Neurol. 2018; 14(3): 168-81.

PubMed Abstract | Publisher Full Text | Free Full Text | F1000 Recommendation

71. F Bonham LW, Geier EG, Steele NZR, et al.: Insulin-Like Growth Factor Binding Protein 2 Is Associated With Biomarkers of Alzheimer's Disease Pathology and Shows Differential Expression in Transgenic Mice. Front Neurosci. 2018; 12: 476 .

PubMed Abstract | Publisher Full Text | Free Full Text | F1000 Recommendation

72. F Moreno-Gonzalez I, Edwards lii G, Salvadores N, et al.: Molecular interaction between type 2 diabetes and Alzheimer's disease through cross-seeding of protein misfolding. Mol Psychiatry. 2017; 22(9): 1327-34.

PubMed Abstract | Publisher Full Text | Free Full Text | F1000 Recommendation

73. Szkudelski T: The mechanism of alloxan and streptozotocin action in $B$ cells of the rat pancreas. Physiol Res. 2001; 50(6): 537-46.

PubMed Abstract

74. Furman BL: Streptozotocin-Induced Diabetic Models in Mice and Rats. Curr Protoc Pharmacol. 2015; 70(1): 5.47.1-5.47.20.

PubMed Abstract | Publisher Full Text

75. F Sun $\mathrm{P}$, Ortega G, Tan $\mathrm{Y}$, et al:: Streptozotocin Impairs Proliferation and Differentiation of Adult Hippocampal Neural Stem Cells in Vitro-Correlation With Alterations in the Expression of Proteins Associated With the Insulin With Alterations in the Expression of Proteins

PubMed Abstract | Publisher Full Text | Free Full Text | F1000 Recommendation

76. Stanley M, Macauley SL, Holtzman DM: Changes in insulin and insulin signaling in Alzheimer's disease: cause or consequence? J Exp Med. 2016; 213(8): 1375-85. PubMed Abstract | Publisher Full Text | Free Full Text

77. Hughes RE, Nikolic K, Ramsay RR: One for All? Hitting Multiple Alzheimer's Disease Targets with One Drug. Front Neurosci. 2016; 10: 177. PubMed Abstract | Publisher Full Text | Free Full Text

78. Claxton A, Baker LD, Hanson A, et al.: Long-acting intranasal insulin detemir improves cognition for adults with mild cognitive impairment or early-stage Alzheimer's disease dementia. J Alzheimers Dis. 2015; 44(3): 897-906. PubMed Abstract | Publisher Full Text

79. F Kullmann S, Heni M, Veit R, et al:: Intranasal insulin enhances brain functional connectivity mediating the relationship between adiposity and subjective feeling of hunger. Sci Rep. 2017; 7(1): 1627. PubMed Abstract | Publisher Full Text | Free Full Text | F1000 Recommendation

80. $\mathrm{F}$ Gabbouj $\mathrm{S}$, Natunen $\mathrm{T}$, Koivisto $\mathrm{H}$, et al.: Intranasal insulin activates Akt2 signaling pathway in the hippocampus of wild-type but not in APP/PS1 Alzheimer model mice. Neurobiol Aging. 2019; 75: 98-108. PubMed Abstract | Publisher Full Text | F1000 Recommendation

81. F Ospina-Romero M, Abdiwahab E, Kobayashi L, et al:: Rate of Memory Change Before and After Cancer Diagnosis. JAMA Netw Open. 2019; 2(6): e196160. PubMed Abstract | Publisher Full Text | Free Full Text | F1000 Recommendation

82. Okereke OI, Meadows ME: More Evidence of an Inverse Association Between Cancer and Alzheimer Disease. JAMA Netw Open. 2019; 2(6): e196167. PubMed Abstract | Publisher Full Text

83. F Majd S, Power J, Majd Z: Alzheimer's Disease and Cancer: When Two Monsters Cannot Be Together. Front Neurosci. 2019; 13: 155. PubMed Abstract | Publisher Full Text | Free Full Text | F1000 Recommendation 


\section{Open Peer Review}

\section{Current Peer Review Status:}

\section{Editorial Note on the Review Process}

Faculty Reviews are review articles written by the prestigious Members of Faculty Opinions. The articles are commissioned and peer reviewed before publication to ensure that the final, published version is comprehensive and accessible. The reviewers who approved the final version are listed with their names and affiliations.

\section{The reviewers who approved this article are:}

\section{Version 1}

\section{W Todd Miller}

Department of Physiology and Biophysics, Stony Brook University, Stony Brook, NY, USA

Competing Interests: No competing interests were disclosed.

\section{Cunming Duan}

Department of Molecular, Cellular, and Developmental Biology, University of Michigan, Ann Arbor, MI, USA

Competing Interests: No competing interests were disclosed.

\section{Douglas Yee}

Departments of Medicine and Pharmacology, Masonic Cancer Center, University of Minnesota, Minneapolis, MN, USA

Competing Interests: Research Funding from Boehringer Ingleheim. He is the coordinating investigator of a clinical trial testing a drug that neutralizes IGF action. "Not the topic of this review, but relevant."

\section{Derek LeRoith}

Division of Endocrinology, Diabetes and Bone Disease, Icahn School of Medicine at Mount Sinai, New York, NY, USA

Competing Interests: No competing interests were disclosed. 
The benefits of publishing with F1000Research:

- Your article is published within days, with no editorial bias

- You can publish traditional articles, null/negative results, case reports, data notes and more

- The peer review process is transparent and collaborative

- Your article is indexed in PubMed after passing peer review

- Dedicated customer support at every stage

For pre-submission enquiries, contact research@f1000.com 